\title{
HUBUNGAN JENIS KELAMIN, TINGKAT PENDIDIKAN DAN PENGETAHUAN TERHADAP KEJADIAN SKABIES PADA SANTRI PONDOK PESANTREN QOTRUN NADA KOTA DEPOK
}

\author{
THE PREVALENCE OF SCABIES CORRELATED TO SEX, EDUCATION LEVEL, \\ AND KNOWLEDGE ON QOTRUN NADA ISLAMIC BOARDING SCHOOL STUDENTS \\ DEPOK CITY
}

\author{
Zaira Naftassa, Tiffany Rahma Putri \\ Program Studi Kedokteran, Fakultas Kedokteran dan Kesehatan Universitas Muhammadiyah Jakarta \\ Korespondensi: Zaira Naftassa. Email: naftassa@gmail.com
}

ABSTRAK

Skabiesis merupakan penyakit kulit yang disebabkan oleh infestasi dan sensitisasi tungau Sarcoptes Scabiei Varietas Hominis. Penyakit ini menginfeksi sebagian besar pelajar yang tinggal di asrama, hal ini bisa disebabkan oleh beberapa kemungkinan, diantaranya: kurangnya higienitas kamar tidur dan personal. Penelitian ini bertujuan untuk mengetahui hubungan jenis kelamin, tingkat pendidikan dan pengetahuan terhadap kejadian penyakit skabies di Pondok Pesantren Qotrun Nada Cipayung, Depok tahun 2017. Penelitian ini bersifat deskriptif analitik dengan desain cross sectional. Subjek penelitian ini adalah santri MTs dan MA Pondok Pesantren Qotrun Nada dengan jumlah sampel sebanyak 50 santri. Analisis data berdasarkan kejadian penyakit skabies menggunakan uji Chi-Square $(p<0,05)$ dan CI 95\%. Hasil penelitian menunjukan bahwa terdapat hubungan antara jenis kelamin, tingkat pendidikan dan pengetahuan terhadap penyakit skabies.

Kata Kunci: Pengetahuan, Pendidikan, Skabiesis

\section{ABSTRACT}

Scabiesis is one of many skin disease caused by an infestation and sensitization of Sarcoptes scabiei var. Hominis. It can infected almost students living in boarding school, caused by several abilites, such as room facilities and personal hygiene. This study held on Qotrun Nada Islamic Boarding School, Cipayung, Depok, on year 2017, and focused on prevalence of scabies correlated to sex, education level and knowledge of students. The study used cross - sectional analytical- descriptive methode. Subjects were all students of Qotrun Nada Islamic Boarding School, and 50 samples were taken. All data based on prevalence of scabies were analized by Chi - square test $(p<0,05)$ and CI 95\%. The result showed positive correlation among sex, education level, and knowledge towards scabies. Some suggenstions could be given by school management and government to take actions on demolishing the parasite and took some preventions against S. Scabiei infection to maintain students healthcare on boarding school.

Keywords: Knowledge, Education, Scabiesis

\section{PENDAHULUAN}

Penyakit kulit merupakan salah satu penyakit yang masih menjadi masalah kesehatan masyarakat Indonesia. Menurut data depkes RI prevalensi penyakit kulit diseluruh Indonesia ditahun 2012 adalah $8,46 \%$ kemudian meningkat ditahun 2013 sebesar $9 \%$ dan skabies menduduki urutan ketiga dari 12 penyakit kulit yang tersering (Badan Penelitian dan Pengembangan Kesehatan Republik Indonesia, 2013). Sebanyak
14 provinsi mempunyai prevalensi penyakit kulit diatas prevalensi nasional, yaitu Nangroe Aceh Darussalam, Sumatera Barat, Bengkulu, Bangka Belitung, DKI Jakarta, Jawa Barat, Jawa Tengah, DI Yogyakarta, Nusa Tenggara Timur, Kakimantan Tengah, Kalimantan selatan, Sulawesi Tengah, dan Gorontalo (Badan Penelitian dan Pengembangan Kesehatan Republik Indonesia, 2013).

Skabies adalah penyakit kulit menular yang disebabkan oleh infestasi dan sensitisasi Sarcoptes 
scabiei var. hominis. Tungau ini tidak bisa terbang atau melompat tapi merangkak dengan kecepatan $2,5 \mathrm{~cm}$ per menit pada kulit yang hangat. Tungau skabies dapat bertahan selama 2-6 jam pada suhu ruangan dan masih tetap mampu berpenetrasi. Skabies menular dengan dua cara yaitu secara kontak langsung dan tidak langsung (Handoko, 2009). Penyakit skabies diperkirakan mencapai sekitar 300 juta kasus per tahunnya di seluruh dunia dan menyerang semua umur, jenis kelamin, ras, serta tingkat sosioekonomi. Tingkat kejadian skabies dalam literatur terbaru mencapai sekitar dari $0,3 \%$ sampai $46 \%$, namun anak-anak paling rentan terjangkit skabies. Masyarakat dengan sumber daya yang rendah sangat rentan terjangkit penyakit skabies. Faktor yang berperan pada tingginya angka kejadian skabies di negaranegara berkembang terkait dengan kemiskinan yang berhubungan dengan rendahnya tingkat kebersihan diri (personal hygiene), akses air yang sulit, dan kepadatan penduduk (Strong and Johnstone, 2011).

Penyakit ini banyak ditemukan pada tempat dengan penghuni padat seperti asrama tentara, penjara dan pondok pesantren. Tempat yang berpenghuni padat ditambah lingkungan yang tidak terjaga kebersihannya akan memudahkan transmisi dan penularan tungau skabies. Penyakit skabies terjadi karena personal hygiene yang kurang baik karena perilaku kebiasaan seperti pinjam meminjam alat dan bahan perlengkapan mandi (sabun, sarung atau handuk), jarang membersihkan tempat tidur (menjemur kasur, mengganti sarung bantal dan sprei). Untuk melakukan personal higiene seperti mandi, cuci dan kakus (MCK) sumber air berasal dari sumur bor kemudian dialirkan pada bak mandi besar. Hal ini terjadi terutama pada santri pondok pesantren karena padatnya aktivitas yang dilakukan oleh mereka sehingga kebersihan sering dianggap sepele (Muafidah dan Santoso, 2017).

\section{METODE}

Penelitian ini merupakan penelitian deskriptif analitik dengan menggunakan desain studi cross sectional. Penelitian ini dilakukan di Pondok Pesantren Qotrun Nada kota Depok pada bulan September Tahun 2017. Sampel pada penelitian ini adalah santriwan dan santriwati kelas VII - XII dengan jumlah 50, dan dilakukan secara accidental sampling. Analisis pada penelitian ini menggunakan uji chi-square $\left(\mathrm{x}^{2}\right)$ dengan analisis univariat dan bivariat.

\section{HASIL DAN PEMBAHASAN}

Hasil analisis univariat menunjukkan bahwa $82 \%$ responden mengalami skabies (Tabel 1). Angka ini masih tinggi dan seharusnya dilakukan pencegahan agar penyakit skabies tidak semakin menyebar. Meskipun tidak menyebabkan kematian, namun skabies dapat mempengaruhi konsentrasi belajar para santriwan dan santriwati karena gatal pada malam hari yeng disebabkan karena aktifitas tungau lebih tinggi pada suhu yang lebih lembab. Selain itu juga, kepadatan hunian menjadi salah satu penyebab terjadinya skabies, dengan kepadatan hunian yang tinggi menjadikan kontak langsung antar santri menjadi tinggi sehingga mudah untuk tertularnya skabies. Kejadian skabies lebih banyak terjadi pada responden perempuan lebih banyak 52\% dari responden laki-laki 48\%. Berdasarkan tingkat pendidikan, diketahui bahwa responden tingkat SMP lebih banyak $62 \%$ dari responden tingkat SMA 32\% sedangkan berdasarkan pengetahuan, responden dengan pengetahuan baik lebih tinggi $62 \%$ dibanding responden dengan pengetahuan kurang baik $38 \%$.

Tabel 1. Karakteristik Responden Berdasarkan Kejadian Skabies, Jenis Kelamin, Tingkat Pendidikan Dan Pengetahuan

\begin{tabular}{lcc}
\hline \multicolumn{1}{c}{$\begin{array}{c}\text { Karakteristik } \\
\text { Responden }\end{array}$} & Jumlah & Persentase \\
\hline Kejadian Skabies & & \\
Positif & 41 & 82.0 \\
Negatif & 9 & 18.0 \\
& & \\
Jenis Kelamin & 24 & 48.0 \\
Laki-Laki & 26 & 52.0 \\
Perempuan & & \\
Tingkat Pendidikan & 31 & 62.0 \\
SMP & 19 & 32.0 \\
SMA & & \\
Pengetahuan & & \\
Kurang baik & 19 & 38.0 \\
Baik & 31 & 62.0 \\
\hline
\end{tabular}

Berdasarkan tabel 2 diketahui bahwa variabel jenis kelamin, tingkat pendidikan dan pengetahuan memiliki hubungan yang signifikan dengan kejadian skabies sebab memiliki nilai pvalue dibawah 0.05. Pada jenis kelamin, 
ditemukan bahwa $66.7 \%$ responden laki-laki mengalami skabies dan $96.2 \%$ responden perempuan mengalami skabies. Pada variabel tingkat pendidikan, diketahui bahwa $96.8 \%$ responden dengan tingkat pendidikan SMP mengalami skabies, $57.9 \%$ responden dengan tingkat pendidikan SMA mengalami kejadian skabies. Pada poin pengetahuan, diketahui bahwa $100 \%$ responden yang memiliki pengetahuan kurang baik mengalami skabies dan $71 \%$ responden yang memiliki pengetahuan baik mengalami skabies.

Hasil analisis menunjukan bahwa adanya hubungan antara jenis kelamin dengan kejadian skabies dengan nilai $\mathrm{p}<$ dari 0.05 yaitu 0.009 . Pada penelitian ini, santri perempuan lebih banyak mengalami skabies yaitu $96.2 \%$. Penelitian ini tidak sejalan dengan penelitian yang dilakukan oleh Ratnasari yang menyebutkan bahwa terdapat hubungan yang bermakna antara jenis kelamin terhadap kejadian penyakit scabies (Ratnasari dan Sungkar, 2014). Penelitian ini juga tidak sejalan dengan penelitian Al Audhah yang menyebutkan bahwa laki-laki lebih berisiko terkena skabies sebanyak 24 kali dibandingkan perempuan (Al Audhah et al., 2012). Hal ini menunjukkan bahwa baik jenis kelamin laki-laki maupun perempuan memiliki peluang yang sama untuk mengalami scabies (Handoko, 2009). Selain itu, jumlah kamar yang tidak sesuai dengan santri yang ada, semakin meningkatkan risiko terjadinya kejadian penyakit skabies sehingga terjadi kepadatan penghuni dalam kamar santri tersebut. Kepadatan penghuni ini menjadi salah satu faktor yang berperan dalam penularan penyakit scabies (Notoatmodjo, 2007).

Tabel 2. Hubungan Jenis Kelamin, Tingkat Pendidikan Dan Pengetahuan Terhadap Kejadian Skabies

\begin{tabular}{|c|c|c|c|c|c|c|c|c|}
\hline \multirow{3}{*}{ Variabel } & \multicolumn{4}{|c|}{ Kejadian Skabies } & \multirow{3}{*}{ Pvalue } & \multirow{3}{*}{ OR } & \multicolumn{2}{|c|}{$95 \% \mathrm{CI}$} \\
\hline & \multicolumn{2}{|c|}{ Positif } & \multicolumn{2}{|c|}{ Negatif } & & & & \\
\hline & n & $\%$ & $\mathbf{n}$ & $\%$ & & & Lower & upper \\
\hline \multicolumn{9}{|l|}{ Jenis Kelamin } \\
\hline Laki-Laki & 16 & 66.7 & 8 & 33.3 & 0.009 & 0.080 & 0.009 & 0.702 \\
\hline Perempuan & 25 & 96.2 & 1 & 3.8 & & & & \\
\hline \multicolumn{9}{|c|}{ Tingkat Pendidikan } \\
\hline SMP & 30 & 96.8 & 1 & 3.2 & 0.001 & 21.818 & 2.440 & 195.075 \\
\hline SMA & 11 & 57.9 & 8 & 42.1 & & & & \\
\hline \multicolumn{9}{|l|}{ Pengetahuan } \\
\hline Kurang baik & 19 & 100 & 0 & 0 & 0,009 & 1.049 & 1.125 & 1.765 \\
\hline Baik & 22 & 71 & 9 & 29 & & & & \\
\hline
\end{tabular}

Variabel tingkat pendidikan diketahui memiliki hubungan yang signifikan dengan kejadian skabies, dengan nilai $\mathrm{p}=0.001$. Pada penelitian ini santri SMP/Tsanawiyah lebih banyak mengalami skabies (96.8\%) dari pada santri SMA/Aliyah. Pada penelitian ini prevalensi skabies berhubungan dengan tingkat pendidikan santri. Prevalensi skabies lebih rendah pada santri yang memiliki tingkat pendidikan aliyah dibandingkan tsanawiyah. Hasil penelitian ini sesuai dengan laporan Ratnasari yang menyatakan prevalensi skabies pada santri aliyah lebih rendah dibandingkan tsanawiyah (Ratnasari dan Sungkar, 2014). Wahjoedi juga melaporkan bahwa prevalensi skabies berhubungan dengan pendidikan, yaitu prevalensi skabies lebih tinggi pada santri tsanawiyah dibandingkan Aliyah (Wahjoedi, 2008). Kuspriyanto pada penelitiannya di pesantren di Pasuruan, Jawa Timur melaporkan hubungan antara prevalensi skabies dengan tingkat pendidikan (Kuspriyanto, 2013).

Tingkat pendidikan berhubungan dengan usia, santri tsanawiyah memiliki usia lebih muda dari santri aliyah. Usia responden merupakan karakteristik yang membedakan tingkat kedewasaan seseorang. Usia seseorang demikian besarnya dalam memengaruhi pengetahuan, sikap, dan perilaku. Dalam kaitannya dengan kejadian skabies pada seseorang, pengalaman keterpaparan sangat berperan karena mereka yang berumur 
lebih tinggi dan mempunyai pengalaman terhadap skabies berpotensi lebih baik dalam mengetahui cara pencegahan serta penularan penyakit skabies. Di beberapa negara yang sedang berkembang, prevalensi skabies cenderung tinggi pada anakanak serta remaja (Handoko, 2009).

Hasil analisis bivariat menunjukan bahwa adanya hubungan antara pengetahuan dengan kejadian skabies dengan nilai $\mathrm{p}=0.009$. Data penelitian menunjukan bahwa responden dengan pengetahuan kurang baik lebih banyak menderita skabies dengan presentase $100 \%$. Penelitian ini sejalan dengan penelitian ibadurrahmi et al. yang menyatakan bahwa adanya hubungan antara pengetahuan dengan kejadian scabies (Ibadurrahmi et al., 2016). Hasil penelitian ini juga sejalan dengan penelitian Rohmawati yang menyebutkan bahwa dari 155 santri, 81,58\% santri berpengetahuan kurang lebih banyak yang menderita scabies (Rohmawati, 2010). Hal ini didukung oleh penelitian Hilma yang menyebutkan bahwa prevalensi skabies lebih tinggi terjadi pada santri dengan pengetahuan kurang, yaitu dari 46 santri yang berpengetahuan kurang, 28 santri menderita skabies $(60,9 \%)$ (Hilma dan Ghazali, 2014).

Pengetahuan dapat diketahui jika seseorang telah berhubungan dengan objek tersebut yang mana sebagian besar pengetahuan dapat diperoleh dari melihat dan mendengar. Pengetahuan merupakan awal pengenalan terhadap suatu objek yang diamati, sehingga jika pengetahuan kurang baik terhadap suatu objek maka akan memengaruhi perilaku yang akan dilakukan. Masih banyaknya santri yang tidak tahu mengenai cara penularan skabies berdampak pada kontinuitas penyakit tersebut di kalangan santri (Notoatmodjo, 2007).

\section{SIMPULAN DAN SARAN}

Berdasarkan hasil analisis dan pembahasan penelitian diatas, dapat disimpulkan bahwa penyakit skabies di pondok pesantren masih terbilang tinggi, sehingga dibutuhkan intervensi untuk menurunkan angka kejadian tersebut dan upaya pencegahannya. Penyakit skabies terjadi disebabkan oleh banyak faktor yang pada penelitian kali ini faktor jenis kelamin, tingkat pendidikan dan pengetahuan memiliki hubungan yang signifikan dengan kejadian skabies.

Diharapkan adanya kerjasama antara pengurus pondok pesantren, guru, dan pemerintah untuk menindak lanjuti dalam upaya penanggulangan dan pencegahan penyakit skabies di pondok pesantren, khususnya pondok pesantren Qotrun Nada Depok.

\section{DAFTAR PUSTAKA}

Al Audhah, N., Rahmah Umniyati, S. dan Ser Siswati, A. 2012. Faktor resiko skabies pada siswa pondok pesantren (Kajian di Pondok Pesantren Darul Hijrah, Kelurahan Cindai Alus, Kecamatan Martapura, Kabupaten Banjar,Provinsi Kalimantan Selatan. Jurnal Buski, 4(1), pp. 14-22.

Badan Penelitian dan Pengembangan Kesehatan Republik Indonesia. 2013. Riset Kesehatan Dasar (RISKESDAS) 2013, Badan Penelitian dan Pengembangan Kesehatan Kementerian Kesehatan RI. doi: 1 Desember 2013.

Handoko, R. P. 2009. Skabies: Ilmu Penyakit Kulit, in Ilmu Penyakit Kulit dan Kelamin. $5^{\text {th }}$ Ed. Pp: $25-122$.

Hilma, U. dan Ghazali, L. 2014 Faktor-Faktor yang Mempengaruhi Kejadian Skabies di Pondok Pesantren Mlangi Nogotirto Gamping Sleman Yogyakarta. Jkki, 6(3), Pp: 148-157.

Ibadurrahmi, H., Veronica, S. dan Nugrohowati, N. 2016. Faktor-Faktor yang Berpengaruh Terhadap Kejadian Penyakit Skabies pada Santri di Pondok Pesantren Qotrun Nada Cipayung Depok Februari Tahun 2016. Jurnal Profesi Medika, 10(1). Pp: 33-45.

Kuspriyanto . 2013. Pengaruh Sanitasi Lingkungan dan Perilaku Sehat Santri Terhadap Kejadian Skabies di Pondok Pesantren Kabupaten Pasuruan Jawa Timur. Jurnal Geografi, 11(21). Pp: 64-73.

Muafidah, N. dan Santoso, I. 2017. Hubungan Personal Higiene dengan Kejadian Skabies pada Santri Pondok Pesantren Al Falah Putera Kecamatan Liang Anggang Tahun 2016 The Relation of Personal Hygiene with The Incidence of Scabies at Al Falah Male Boarding School Students 
Sub-district of Lian. 1(1). Pp: 1-9.

Notoatmodjo, S. 2007. Ilmu Perilaku Kesehatan. Jakarta: PT Rineka Cipta.

Rohmawati, R.N. 2010. Hubungan Antara Faktor Pengetahuan dan Perilaku Dengan Kejadian Skabies Di Pondok Pesantren Al-Muayyad Surakarta. Universitas Muhammadiyah Surakarta. Available at: http://eprints.ums.ac.id/9272/.

Ratnasari, A. F. dan Sungkar, S. 2014. Prevalensi Skabies dan Faktor-faktor yang Berhubungan di Pesantren X, Jakarta Timur. Prevalensi Skabies. 7(1). doi: 10.23886/ejki.2.3177.

Strong, M. and Johnstone, P. 2011. Interventions for treating scabies ( Review ), Evid-Based Child Health: A Cochrane Review Journal, 6(6). Pp: 1790-1862. doi: 10.1002/ebch.861.

Wahjoedi, I. 2008. Faktor Risiko Kejadian Penyakit Skabies pada Pondok Pesantren di Kabupaten Kulon Progo (Studi Ekologi). Universitas Gajah Mada. Available at: http://etd.repository.ugm. ac.id/index.php?mod=penelitian_detail\&sub=PenelitianDetail\&act=view\&typ=html\&buku_ $\mathrm{id}=37781$. 